\title{
Farmer's Perception Towards Agricultural Technology. The Case of Improved Highland Maize Varieties Adoption in Selected Kebeles of Toke Kutaye District, West Showa Zone
}

\author{
Dawit Milkias $^{1 *} \quad$ Daniel Belay $^{2} \quad$ Gemechu Shale Ogato ${ }^{2}$ \\ 1.Ambo Agricultural Research Center, Ethiopian Institute of Agricultural Research/EIAR/, Ambo, Ethiopia \\ 2.Department of Rural Development and Agricultural Extension, Institute of Cooperatives and Development \\ Studies, Ambo University, Ethiopia
}

\begin{abstract}
s
The study aims to reveal farmer's perceptions towards improved highland maize varieties in selected kebeles of Toke kutaye districts. In this paper, farmer's perception towards improved highland maize varieties were investigated or measured using a scale with items developed for the purpose of this study. Two stage sampling procedures were followed in order to draw 150 sample respondents. Responses of sample respondents on the perception related were analyzed using Likert type scale. Based on the level of agreements the result revealed that perception on disease resistant, high yielding potential of the varieties, early maturity of the varieties, agro ecological suitability and availability of seed at the right time and quality showed relatively best performance of the varieties in the study area. Whereas, perception on technological availability of the varieties indicates relatively poorest agreement compared to all other characteristics of level of agreements considered. Even if the advantages of the varieties are more for households of the study area, some farmers are discouraged to adopt the variety because of reasons such as demand more inputs, the lack of credit service, market problem, insect pest problem, lack of awareness and extension support on the technology. Therefore, the extension and research system have to look in to these factors to give solution for the adoption of the variety.
\end{abstract}

Keywords: Highland maize, Perception, Likert type scale, agreements

DOI: $10.7176 / \mathrm{JESD} / 10-5-09$

Publication date:March $31^{\text {st }} 2019$

\section{Introduction}

\subsection{Background of the study}

Maize is the most widely grown and consumed staple crop in Africa with more than 300 million Africans depending on it as their main food source. It is the staple food for 24 million households in east and southern Africa and is annually planted over an area of 15.5 million hectares. Research in to maize improvement practices to optimize grain yields is a priority for governments in the region because of the critical role the crop plays in ensuring food security [3].

In Ethiopia's economy Agriculture continues to be the dominant sector, accounting for 51\% of the GDP in 2009 [20]. Within agriculture, cereals play a central role accounting for roughly $60 \%$ of rural employment, $80 \%$ of total cultivated land. Among cereals, maize is the most important crop in terms of production and contributes significantly to the economic and social development of Ethiopia [10]. Maize cultivation is a largely smallholder phenomenon, which the smallholder farmers that comprise about $80 \%$ of Ethiopia's population are both the primary producers and consumers of maize [7]. While maize already plays a critical role in smallholder livelihood and food security of the country, this role can be expanded. Because of lack of modern way of farming, agricultural technologies, the production was 2.2 tons per hectare in 2008/09 with a potential for 4.7 tons per hectare according to on-farm field trials, when cultivated with fertilizer, hybrid seed, and improved farm management practices [18]. The implication is that if smallholder farmers have got the ability to adopt the improved maize technologies, they can produce more.

Technology adoption is a complex and a dynamic process that is determined by many factors such as perceived characteristics of the technologies, farmer circumstances and conditions. The adopter perception model suggests that the perceived attributes of innovations condition adoption behavior [4, 5]. Thus adoption depends on users' judgments of the value of the technology to them. Users' judgments depends on many factors some personal, others reflecting on utility and efficiency of the technology. Adoption or rejection of technologies by users may reflect rational decision characteristics of the technologies under investigation. Users will reject a technology that is not relevant to their needs, not suited to their work environment and one that may interfere with other activities that are considered to be important. These subjective technology attributes have shown to significantly condition technology adoption decisions [13].

Their omissions in adoption model may bias the results of the factors determining adoption decision of users [5].

Economists investigating consumer demand have accumulated considerable evidence showing that 
consumers generally have subjective preferences for characteristics of products attributes. However, when investigating adoption of new agricultural technologies, economists have lagged behind investigating how users' (the consumer of agricultural technologies) subjective perceptions of technology characteristics affect their adoption decisions. Focusing on the perceptions of farmers towards technologies may provide the answers since they deal with the technologies and they probably perceive technologies differently than researchers and extension agents.

In West Showa Zone the national agricultural research system has generated a number of improved technologies and recommendations such as crop variety, agronomic practices, crop protection measures as well as other technical advises and practices. In Toke kutaye district improved highland maize technologies are being promoted by research center. The technologies promoted include improved highland maize varieties, recommended fertilizer rates and types, improved agronomic and weed control practices. Having implemented many interventions, this study was mainly done to know the profile of farmer respondents and to examine their perception towards improved highland maize varieties, in the study area.

Objectives of this study are to identify the farmers' perceptions towards the adoption of new highland maize varieties and provide policy recommendation towards improved highland maize varieties.

\section{Empirical studies on the adoption of agricultural technologies \\ 2.1 Empirical studies on farmers adoption behavior}

As a contribution to this innovation process, it is tried to determine the adoption of innovative systems by examining the socio-economic determinants behind their adoption. It is well known that farmers often fail to follow the technical advice provided by the extension services and do not always adopt technical innovations [9]. This makes assessing the factors that can enhance innovation of the adoption of useful step to accept appropriate technology development and suitable policy strategies to improve the likelihood of adoption of innovations entailing lower chemical input use. Additionally, farmer's expectations about future policy and market change can play an important role as they can modify farmer's perceived utility of innovations. The effectiveness numerous determinants related to farmer's personal attitudes toward risk, change and uncertainty which can significantly influence adoption as they can reduce the perceived utility of innovations, and be associated with aversion to change [1]. Adoption also affected with production inputs and constraints such as financial capacities, access to water resources, farm size [6]. These contexts are mainly captured through geographical indicators such as regional appurtenance, distance to other innovators and distance to market, demographic pressure, and the presence of extension services [14]. They are also related to farmers' characteristics such as the number of contacts with extension agents, the involvement of farmers in research programs, or the affiliation to a farmer's union. Generally, adoption is determined by different factors like policy and market change, attitude towards risk and other factors.

Many studies have focused on the relationships of key variables to the adoption behavior of farmers. A review of previous studies is important as it provides some conceptual and theoretical basis for identifying the relevant variables to be included in the analysis. The category variables are the most common household characteristics which are mostly related with farmers' adoption behavior. Age, education and farming experience have been reviewed in this study. Different agricultural technology adoption studies revealed conflicting results on the influence of age in adoption. The study conducted by [16] on factors affecting adoption of improved maize seed and fertilizer in northern Tanzania, indicated that farmer's age did not significantly influence improved technology adoption.

Farmers' subjective perceptions of new technologies in light of prevailing socioeconomic environment condition their adoption behavior. The concept of adopter perception can now be found in varied agricultural economics literature [4]. Quantitative studies that have considered farmers' perception in context of adoption decisions have included farmers' perception of new technology. Farmers are considered to have subjective preferences for specific characteristics inherent in new technologies or innovations. These preferences are assumed to play a significant role in technology adoption. Adoption of technologies by farmers reflects rational decision making based up on farmers perceptions of appropriateness of the characteristics of the technology under investigation.

A large number of personal, situation and social characteristics of farmers have been found to be related to their adoption behavior [19]. Based on this idea, [11] tried to compare the adoption behavior of both adopters and non-adopters. Adopters of farming practices tend to be middle aged, have a high rate of literacy and a higher level of formal education, operate large sized holdings, own the land they operate, have a relatively high income and economic status, are commercial in farming orientation, have relatively high level of social participation, and tend to be cosmopolite in orientation, have relatively high level of extension contact, and belong to upper socio-economic status categories. Non-adopters, on the other hand, are relatively old in age, have a low rate of literacy and level of formal education, operate smallholdings, are mostly share-croppers or small and marginal farmers, belong to low income and economic status, have a subsistence orientation to farming, have a low level 
of extension contact, and come from low socioeconomic status categories.

\section{METHODOLOGY OF THE STUDY}

\subsection{DESCRIPTION OF THE STUDY AREA}

The study was conducted in Oromia Region, West Shoa Zone, Toke Kutaye district which is located west of Addis Ababa at a distance of $128 \mathrm{~km}$ and $12 \mathrm{~km}$ west from the capital town of West Shoa Zone, Ambo. Geographically, it lies between $8^{0} 47^{\prime}$ to $9^{0} 21$ latitudes and $37^{0} 32$ to $37^{0} 03^{\prime} \mathrm{E}$ longitude. The district borders with Midakegn district in the North, Dirre Inchini in the South, Ambo district in the East and Chalia district in the West. The district contains 24 kebeles (20 rural and 4 urban kebeles). The total amount of population is 134,767 (66,492 males and 68,275 female). There are 22,895 HH farmers in the district, out of these 20,148 male and 2747 females. The district is estimated about $788.87 \mathrm{~km}^{2}$, accounting for $10.7 \%$ of the total area of West Shoa Zone.

The land use pattern of the district shows that 37,509 ha is cultivated land; 3651 ha is covered with forest, 11,603 ha is grazing land and 26,124 ha with bush and shrubs [22]. The district consists of 27\% arid, 55\% Semiarid and 18\% desert areas [22]. The major crops produced in the district are Teff, Maize, wheat, Sorghum, barley and others [22]. The maximum and minimum altitudes of the study area are 1880 and 3194 m.a.s.1. respectively. Annual rainfall between 800 and $1100 \mathrm{~mm}$. The minimum and maximum temperature $10^{\circ} \mathrm{C}$ and $29^{\circ} \mathrm{C}$ respectively. The soil characteristics are $48 \%$ red soil, $27 \%$ black soil, $25 \%$ red and black mixture. The total livestock, posses 331,134 [22]. The total area of land that can be used for irrigation is 3,048 ha, from this area 1665 he is currently being used [22].

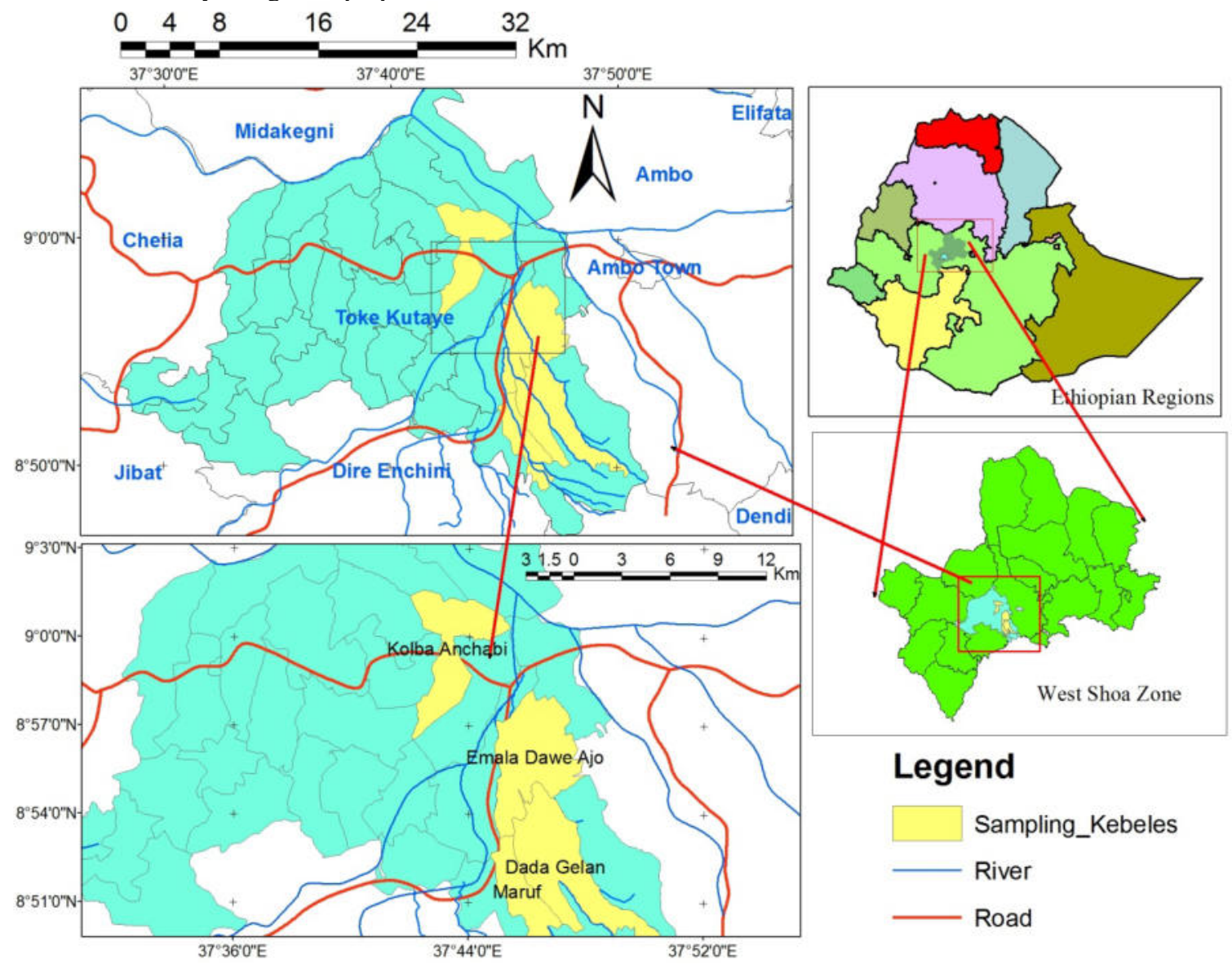

Fig- 1: Map of the study area 


\subsection{Sampling Procedure and Method of Data Collection}

\subsubsection{Sampling Procedure and Sample Size Determination}

Two stage sampling techniques were employed to select the sample respondents. First stage was purposive selection of highland maize growing Kebeles of the districts, followed by selection of sample households. The Kebele identification was made through reviewing secondary data on production potential of maize and dissemination of the improved highland maize technologies and area coverage of the crop. In the second stage 150 sample respondents were chosen using systematic random sampling technique from each kebeles based on probability proportional to size through using the following formula of sample determination:

$$
\begin{aligned}
& n=\begin{array}{c}
\boldsymbol{N} \\
1+\boldsymbol{N}(e) 2
\end{array} \\
& n=\frac{3954}{1+3954(0.08)} \approx 150
\end{aligned}
$$

Where $\mathrm{n}$ is the sample size for the study, $\mathrm{N}$ is the total households of the study area which is $3954, e$ is the maximum variability or margin of error or which is 0.08 in this study, 1 is the probability of the event occurring. The sample size from each kebeles was determined based on their proportion to total share of households residing in each kebeles. TABLE 1: SAMPLE HOUSEHOLDS TO BE SELECTED FOR THE STUDY

\begin{tabular}{rlcc}
\hline No. & Sample kebeles & Households & Sample size \\
\hline 1 & Kolba anchabi & 550 & 21 \\
2 & Maruf & 1031 & 39 \\
3 & Dadagalan & 1123 & 43 \\
4 & Imala Dawo Ajo & 1250 & 47 \\
\hline & Total & $\mathbf{3 9 5 4}$ & $\mathbf{1 5 0}$ \\
\hline
\end{tabular}

Source: Author's compilation, 2017

\subsubsection{METHOD OF DATA COLLECTION}

In order to achieve the stated objectives, primary and secondary data were utilized in this research. The main source of data for the study was primarily field survey which focused on data related to socioeconomic, institutional and demographic characteristics of the respondents, and other related information that were essential for the research purpose. The secondary data sources was collected from published and unpublished materials, which include books, journals, scientific research works and office records. Primary data was collected through the following methods.

\section{A. Focus Group Discussions (FGD)}

For this study one focus groups contain eight members was conducted with active household heads in each selected villages. The purpose of the focus group discussion was to generate in-depth information on some of the survey findings and perceptions of the farmers that may not have been adequately captured by the semistructured questionnaires. The researcher presented various open-ended questions regarding adoption and perceptions on the varieties and other related factors to the discussants to express their own perceptions and response. This technique enabled the researcher to explore what they know or think about the research problem that the questions would cover, and then to verify, confirm and add depth to the results of the household survey.

\subsection{Method of Data Analysis}

\subsubsection{DESCRIPTIVE ANALYSIS:}

Farmers perception towards improved highland maize variety is described and measured based on the agreement level of the respondents perceived during the data collection. Perception was measured using a scale with items developed for the purpose of this study. Responses of sample respondents on the perception related were analyzed using Likert type scale.

Accordingly, the ratings such as strongly disagree(1), disagree(2), neutral(3), agree(4) and strongly agree(5) were used to measure the respondents perception to the technologies and the larger value(5) indicates how farmer perceives the characteristics being presented for evaluation is being embodied and 4,3,2, and 1 in a decreasing manner. A value less than three indicates how the farmer perceives the characteristics under evaluation as poor or negatively. The relative agreement was computed by dividing the mean of each variable to the total mean and multiplied by $100 \%$. 


\section{RESULT AND DISCUSSION}

\subsection{Adoption of Improved highland maize varieties in the study area}

Improvement in production and productivity of a given crop depends, among other things, on presence and use of better and improved varieties. In line with this objective, a lot of efforts have been made by the research system to generate improved varieties of highland maize varieties and as a result, many varieties have been released. Among the released, AMB02SYN1- 'Hora', AMH800-'Arganne', AMH850-'Wenchi', AMH851-'Jibat', and AMH760-'Webi' varieties were introduced to the study area [12]. These all varieties were introduced to the farming community through Ambo agricultural Research Center, MoA and other organizations. Regardless of such intervention, however, adoption of improved highland maize varieties

in

the study area is still low. The level of adoption of improved high land maize variety influences the amount of yield obtained by farmers.

Data set contains 150 farm households and of these, about 104 (69.33) \% households were adopters and about $46(30.67 \%)$ households were non-adopters. Farmers who did not grow improved highland maize variety were considered as non-adopters and while the farmers who grow at least one of the improved highland maize varieties during the 2016 cropping season with some of the recommended agronomic practices (improved variety, seed rate, and fertilizer application rate) were taken as adopters.

In the study area, the average land used for improved highland maize was 0.3125 ha, and the minimum and maximum land coverage for improved highland maize was 0.125 ha and 0.5 ha respectively. The average yield obtained was 11 quintal per hectare and the maximum was 18 quintal while the minimum was 4 quintal. The average gross income from improved highland maize production of the sample adopter households from one season harvesting time 2016/17 production year was $3590 \mathrm{ETB}$, i.e. the minimum and maximum income was 880 ETB and 6300 ETB respectively.

\subsection{Results of Focus Group Discussion}

Finding from focus group discussion confirmed that the newly released varieties were used to increase production and productivity of the farmers. The reason for few farmers using the new highland maize varieties were due to lack of the varieties on time, lack of credit, market problem and lack of enough extension support from development agents were the major problems in the area. FGD discussion explained the role played by women in highland maize cultivation as very crucial. According to farmers of the study area, women role is not restricted to biological, labor and social reproduction; they are also involved in productive role of farming activities. Although they were found to participate in different activities of production process such as sowing, weeding, cultivation, harvest, transport, storage and preparation of threshing field, the nature of participation is not full time because of biological reproduction of child birth and lactation and laborer production which involves the daily regeneration of the labor force through cooking, cleaning, washing, nursing and so on. Making female farmers targets in extension, therefore, makes sense for agricultural and rural development. The focused groups at each study area described important constraints to maize production. The groups also identified and listed the major constraints recognized and agreed on by most participants in the sampled kebeles. The constraints were seed \& high cost of inorganic fertilizers, weak extension services, Wild and domestic animals, weevils, rodents, low maize price and instability of maize price were among the constraints.

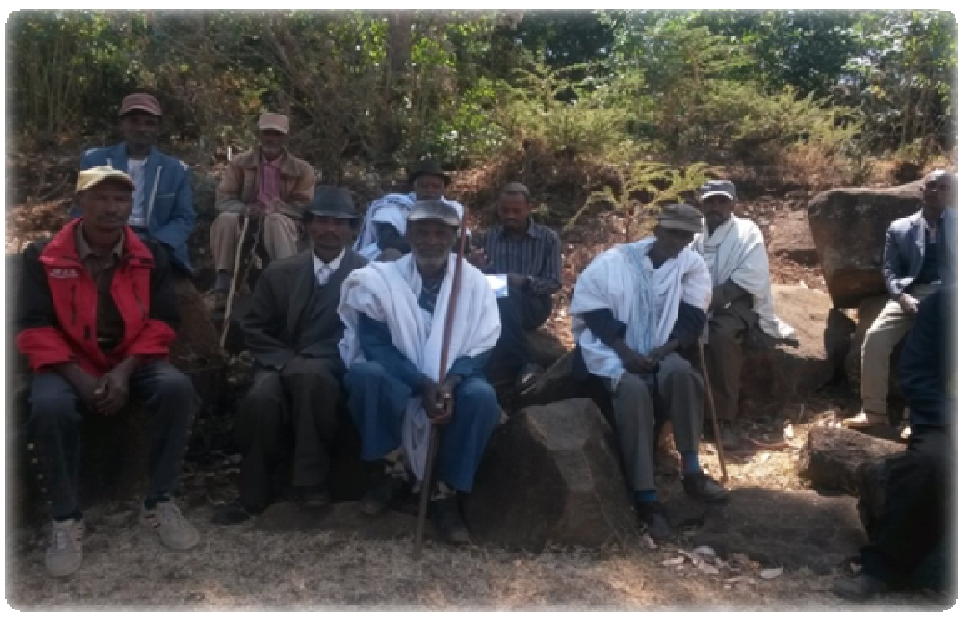

Fig 2: Focus Group Discussion at Kolba Anchabi Pas 


\subsection{Perception on Improved highland maize variety Related Analysis Results}

Technologies are viable only when farmers use them. No matter how well the new technologies work on research stations, if farmers do not have them for use, their development would be in vain [17] cited in [19]. But more trouble will it have been if the farmers' perception of the technologies is not only low but also wrong [19]. Farmers perception towards highland maize variety is described and measured based on the agreement level of the respondents perceived during the data collection. Perception was measured using a scale with items developed for the purpose of this study. Responses of sample respondents on the perception related were analyzed using Likert type scale. Accordingly, the ratings such as strongly disagree(1), disagree(2), no opinion(3), agree(4) and strongly agree(5) were used to measure the respondents perception to the technologies and the larger value(5) indicates how farmer perceives the characteristics being presented for evaluation is being embodied and 4,3,2, and 1 in a decreasing manner. A value less than three indicates how the farmer perceives the characteristics under evaluation as poor or negatively.

Table 2: Farmers' perception on highland maize technology

\begin{tabular}{|c|c|c|c|c|c|c|c|c|}
\hline \multirow[b]{2}{*}{$\begin{array}{l}\text { Level of agreement on IHM } \\
\text { Varieties }\end{array}$} & \multicolumn{5}{|c|}{$\begin{array}{c}\text { Distribution of respondents per perception } \\
\text { category }(\%)\end{array}$} & \multirow[b]{2}{*}{$\begin{array}{c}\text { Mea } \\
\mathrm{n}\end{array}$} & \multirow[b]{2}{*}{$\begin{array}{l}\text { Level of } \\
\text { agreement } \\
(\%)\end{array}$} & \multirow[b]{2}{*}{$\begin{array}{l}\mathrm{Ra} \\
\mathrm{nk}\end{array}$} \\
\hline & $\begin{array}{c}\text { Strongl } \\
\text { y } \\
\text { Disagr } \\
\text { ee }\end{array}$ & $\begin{array}{l}\text { Disagr } \\
\text { ee }\end{array}$ & $\begin{array}{c}\text { Neutr } \\
\text { al }\end{array}$ & $\begin{array}{c}\text { Agre } \\
\mathrm{e}\end{array}$ & $\begin{array}{c}\text { Strong } \\
\text { ly } \\
\text { Agree }\end{array}$ & & & \\
\hline $\begin{array}{l}\text { Technological availability of } \\
\text { IHMV }\end{array}$ & 24.67 & 41.33 & 3.33 & 21.33 & 9.33 & 2.5 & 12.83 & 6 \\
\hline $\begin{array}{l}\text { Perception on disease resistant } \\
\text { capability }\end{array}$ & 8 & 26.67 & 3.33 & 55.33 & 6.67 & 3.26 & 16.73 & 5 \\
\hline $\begin{array}{l}\text { High yielding potential of the } \\
\text { varieties }\end{array}$ & 8 & 19.33 & 6 & 54.67 & 12 & 3.43 & 17.6 & 2 \\
\hline Early maturity of the varieties & 4 & 24 & 8.67 & 60 & 3.33 & 3.35 & 17.2 & 3 \\
\hline Agro ecological suitability & 6.67 & 28.67 & 6 & 42.67 & 16 & 3.33 & 17.04 & 4 \\
\hline $\begin{array}{l}\text { Availability of seed at the right } \\
\text { time and quality }\end{array}$ & 2.01 & 20.13 & 7.38 & 55.03 & 15.44 & 3.62 & 18.6 & 1 \\
\hline Sum of Mean & & & & & & 49 & 100 & \\
\hline Grand Mean & & & & & & 3.25 & & \\
\hline
\end{tabular}

Source: survey data, 2017:

In the study area the sampled respondent's perception on improved highland maize varieties were evaluated with the help of the aforementioned analytical framework. A grand mean of 3.25 (maximum=5; minimum $=1$ ) indicates that the overall perception on level of agreement on the varieties were showed relatively best performance depending on the characteristics among adoption categories. From the level of agreement of improved highland maize varieties, perception on disease resistant, high yielding potential of the varieties, early maturity of the varieties, agro ecological suitability and availability of seed at the right time and quality showed relatively best performance of the varieties in the study area (Appendix, 1). Whereas, perception on technological availability of the varieties indicates relatively poorest agreement compared to all other characteristics of level of agreements considered.

The survey result indicated that, the majority of the sample households perceived that they have adopted the variety due to the above level of agreement over the other as predicted. Even if the advantages of the varieties are more for households of the study area, some farmers are discouraged to adopt the variety because of reasons such as demand more inputs, the lack of credit service, market problem, insect pest problem, lack of awareness and extension support on the technology. Therefore, the extension and research system have to look in to these factors to give solution for the adoption of the variety.

\section{CONCLUSION AND POLICY RECOMMENDATION}

\subsection{Conclusion}

As repeatedly stated improved highland maize varieties production is important in solving food security and poverty problems in agriculture-based economies demand for substantial efforts in improving agricultural production and productivity.

From the level of agreement of improved highland maize varieties, perception on disease resistant, high 
yielding potential of the varieties, early maturity of the varieties, agro ecological suitability and availability of seed at the right time and quality showed relatively best performance of the varieties in the study area. Whereas, perception on technological availability of the varieties indicates relatively poorest agreement compared to all other characteristics of level of agreements considered.

This study was limited in terms of perception on highland maize varieties that were considered at the household level. Only highland maize varieties were examined yet many other improved cereal crops have been introduced in the study area. In future research, it is recommended that more agricultural technologies introduced to farmers in a particular area be examined using the same criteria used in this study, in which case they can be ranked in terms of suitability using both conjoint results and farmer scoring of the agricultural technologies in the particular attributes.

\subsection{Policy Implications}

Farmers are more responsive in adopting improved highland maize varieties if they perceive that those new varieties as compared to the existing varieties give higher grain yield and earliness of the varieties. Thus it would be very important to focus for developing new highland maize varieties for the varieties to have better adoption intensity. Therefore, policy makers and government intervention related with agricultural technology transfer should take significantly influenced level of agreements into consideration.

\section{References}

[1] Abadi Ghadim, A.K.,Pannell, D.J. and Burton, M.P. 2005. Risk, uncertainty and learning in adoption of a crop innovation. Agricultural Economics, 33:1-9.

[2] Abrhaley Gebrelibanos, 2007. Farmers' Perception and Adoption of Integrated Striga Management Technology in Tahtay Adiabo Woreda, Tigray, Ethiopia. An M.Sc Thesis Submitted to School of Graduate Studies, Haramaya University.

[3] African Biotechnology stakeholders Forum(ABSF): Maize Production And Improvement In Sub-Saharan Africa, First published in 2010 by the African Biotechnology Nairobi, Kenya.

[4] Adesina, A. A. and M. M. Zinnah. 1993. Farmer Perceptions and Adoption Decisions: A Tobit Model Application in Sierra Leone. Agricultural Economics, 9: 297-311.

[5] Adessina, A.A. and J.Baidu-Forson, 1995. Farmer's perceptions and adoption of new agricultural technology, Evidence from Burkina Faso and Guinea, Journal of Agricultural Economics, 13:1-9.

[6] Adesina, A. A. and Chianu J. (2002). Determinants of farmers' adoption and adaptation of alley farming technology in Nigeria. Agroforestry System 55: 255-265.

[7] Alemu, D., Wilfred, M., Mandefro, N. and David, J.S. (2008). The maize seed system in Ethiopia: challenges and opportunities in drought prone areas. African Journal of Agricultural Research 3 (4): 305-314.

[8] Ashby, J.A., Quirose, C.A. and Rivers, Y.M., 1989: Farmer participation in technology development: Work with crop varieties. Chabers, R., Pacey, A. and Thrupp, L.A. (Eds), Farmer first. Farmer innovations and agricultural research. Intermediate technology Publications, London, UK.

[9] Bonin, M., Cattan P., 2006. Convergences and differences between the objectives of the financial support facilities and those of the farmers: the case of fallow periods in banana production of Guadeloupe. Fruits, 2006, 61, 9-23.

[10] Central Statistical Agency (CSA) (2011). Agricultural Sample Survey 2010/11 (September- December 2010), Vol. 1, Report on Area and Production of Major Crops, Addis Ababa.

[11] Dasgupta, Satadal, 1989. Diffusion of Agricultural Innovations in Village India. Wiley Eastern Limited, New Delhi. 231p.

[12] Demissew et al., 2013,: Farmers' Perceptions of Maize Production Systems and Breeding Priorities, and Their Implications for the Adoption of New Varieties in Selected Areas of the Highland Agro-Ecology of Ethiopia: Journal of Agricultural Science; Vol. 5, No. 11; 2013: ISSN 1916-9752 E-ISSN 1916-9760: Published by Canadian Center of Science and Education

[13] Ferrington,J., and Martin, A., 1988: Farmer participation in agricultural research: A review of concepts and practices. Agricultural Administration Occasional Paper 9. ODI, London.

[14] Lapar, M.L.A. and Ehui, S. 2004. Factors affecting adoption of dual-purpose forages in the Philippine uplands. Agricultural Systems 81: 95-114.

[15] Mekuria Aweke: November, 2013 Factors Influencing Adoption Of Improved Maize Varieties: The Case Of Goro- Gutu Woreda Of Eastern Hararghe, Ethiopia Zone M.Sc. Thesis Presented To School Of Graduate Studies Of Alemaya University.

[16] Nkonya, E.,T.Schroeder and D.Norman, 1997.Factors affecting adoption of improved maize seed and fertilizer in Northern Tanzania. Journal of Agricultural Economics, 4:1-12

[17] Oladele, O.L., and O.P Fawole, 2007. Farmers' Perception of the Relevance of Agricultural Technologies in South-Western Nigeria. Department of Agricultural Extension and Rural Development, University of Ibadan, Ibadan. J.Hum.Ecol.21(3):191-194. 
[18] Rashid, S., Getnet, K. and Lemma, S. (2010). Maize value chain potential in Ethiopia: Constraints and opportunities for enhancing the system, IFPRI, Working Paper, .

[19] Rahmeto Negash, 2007. Determinants of improved haricot bean production package in Alaba special wored, Southern Ethiopia. M.Sc. Thesis Presented To School of Graduate Studies of Haramaya University.

[20] Tripp, R., 1989: Farmer participation in agricultural research: new directions or old problems? Agriculture and rural probles. Institute of Development Studies

[21] World Bank (2013), World Development Report: Ethiopia a tag lance http://devdata.worldbank.org/AAG/eth aag.pdf

[22] World Development Report (WDR) (2008). Agriculture for Development. The World Bank. Washington DC, USA.

[23] Woreda Office of Agricultural and Rural Development (WOARD), 2016. Activity performance reports. Unpublished document, Toke kutaye, Ethiopia. 


\section{Table in the Appendix}

Table 1: Likert scale results on respondents' perception on improved highland maize variety

\begin{tabular}{|c|c|c|c|c|c|c|c|c|c|c|c|c|c|}
\hline \multirow{2}{*}{ Response } & \multirow{2}{*}{$\begin{array}{c}\text { Descrp } \\
\text { tions }\end{array}$} & \multicolumn{2}{|c|}{$\begin{array}{l}\text { Technological } \\
\text { availability }\end{array}$} & \multicolumn{2}{|c|}{$\begin{array}{c}\text { Disease } \\
\text { Resistant }\end{array}$} & \multicolumn{2}{|c|}{ High yielding } & \multicolumn{2}{|c|}{ Early maturity } & \multicolumn{2}{|c|}{$\begin{array}{l}\text { Agro-ecological } \\
\text { suitability }\end{array}$} & \multicolumn{2}{|c|}{ Availability of seed } \\
\hline & & $\begin{array}{l}\begin{array}{l}\text { Adop } \\
\text { ter }\end{array} \\
\end{array}$ & $\begin{array}{l}\begin{array}{l}\text { Non- } \\
\text { adopter }\end{array} \\
\end{array}$ & Adopter & $\begin{array}{l}\begin{array}{l}\text { Non- } \\
\text { adopter }\end{array} \\
\end{array}$ & $\begin{array}{l}\text { Adop } \\
\text { ter }\end{array}$ & $\begin{array}{l}\text { Non- } \\
\text { adopter }\end{array}$ & $\begin{array}{l}\text { Adop } \\
\text { ter }\end{array}$ & $\begin{array}{l}\text { Non- } \\
\text { adopter }\end{array}$ & $\begin{array}{l}\text { Adop } \\
\text { ter }\end{array}$ & $\begin{array}{l}\text { Non- } \\
\text { adopter }\end{array}$ & $\begin{array}{l}\text { Adop } \\
\text { ter }\end{array}$ & $\begin{array}{l}\begin{array}{l}\text { Non- } \\
\text { adopter }\end{array} \\
\end{array}$ \\
\hline \multirow{2}{*}{$\begin{array}{l}\text { Strongly } \\
\text { disagree }\end{array}$} & $\mathbf{N}$ & 22 & 15 & 8 & 4 & 12 & 0 & 3 & 3 & 0 & 10 & 3 & 0 \\
\hline & $\%$ & 21.15 & 32.61 & 7.69 & 8.7 & 11.54 & 0 & 2.88 & 6.52 & 0 & 21.74 & 2.91 & 0 \\
\hline \multirow{2}{*}{ Disagree } & $\mathbf{N}$ & 49 & 13 & 18 & 22 & 20 & 9 & 26 & 10 & 42 & 1 & 21 & 9 \\
\hline & $\%$ & 47.12 & 28.26 & 17.31 & 47.83 & 19.23 & 19.57 & 25 & 21.74 & 40.38 & 2.17 & 20.39 & 19.57 \\
\hline \multirow{2}{*}{ Neutral } & $\mathbf{N}$ & 1 & 4 & 0 & 5 & 5 & 4 & 10 & 3 & 2 & 7 & 1 & 10 \\
\hline & $\%$ & 0.96 & 8.7 & 0 & 10.87 & 4.81 & 8.7 & 9.62 & 6.52 & 1.92 & 15.22 & 0.97 & 21.74 \\
\hline \multirow{2}{*}{ Agree } & $\mathbf{N}$ & 21 & 11 & 68 & 15 & 51 & 31 & 65 & 25 & 39 & 25 & 57 & 25 \\
\hline & $\%$ & 20.19 & 23.91 & 65.38 & 32.61 & 49.04 & 67.39 & 62.5 & 54.35 & 37.5 & 54.35 & 55.34 & 54.35 \\
\hline \multirow{2}{*}{$\begin{array}{l}\text { Strongly } \\
\text { agree }\end{array}$} & $\mathbf{N}$ & 11 & 3 & 10 & 0 & 16 & 2 & 0 & 5 & 21 & 3 & 21 & 2 \\
\hline & $\%$ & 10.58 & 6.52 & 9.62 & 0 & 15.38 & 4.35 & 0 & 10.87 & 20.19 & 6.52 & 20.39 & 4.35 \\
\hline \multirow{2}{*}{ Total } & $\mathbf{N}$ & 104 & 46 & 104 & 46 & 104 & 46 & 104 & 46 & 104 & 46 & 104 & 46 \\
\hline & $\%$ & 100 & 100 & 100 & 100 & 100 & 100 & 100 & 100 & 100 & 100 & 100 & 100 \\
\hline
\end{tabular}

